\title{
Quality and microbiological changes in minimally processed tropical pumpkin packed in low-density polyethylene bags ${ }^{1,2}$
}

\author{
Natasha Andón-Sánchez ${ }^{3}$, Rosa N. Chávez-Jáuregui , \\ and Linda Wessel-Beaver ${ }^{5}$
}

J. Agric. Univ. P.R. 100(2):203-220 (2016)

\begin{abstract}
Minimally processed tropical pumpkin (Cucurbita moschata) has considerable potential to create new value-added market opportunities for Puerto Rico. The aim of this work was to evaluate the quality and microbiological changes of minimally processed tropical pumpkin packed in low-density polyethylene (LDPE) bags and stored for 20 days. Pumpkin pieces approximately $2 \mathrm{~cm}^{3}$ in size were obtained from two cultivars ('Taína Dorada' and 'Soler'). Pieces were immersed in an antimicrobial solution containing citric acid $(0.2 \%)$ and sodium benzoate $(0.1 \%)$ for $3 \mathrm{~min}$, centrifuged in a salad spinner, packed in LDPE bags with either vacuum or non-vacuum packaging, and stored at $4^{\circ} \mathrm{C} \pm 2$ for a period of 20 days. There were minimum effects of storage time on the chemical and physical characteristics of the pumpkin pieces. The percentage of $O_{2}$ decreased continuously in non-vacuum packaging while the percentage of $\mathrm{CO}_{2}$ increased within the first 72 hours of storage. A sensorial panel judged pumpkin pieces stored for a period of 20 days to be of acceptable quality. A minimally processed product based on pumpkin treated with an antimicrobial solution, packed in LDPE bags (either vacuum or non-vacuum packaging) and stored for 20 days at $4^{\circ} \mathrm{C} \pm 2$ presented safe microbiological levels and acceptable quality for the consumer.
\end{abstract}

Key words: Cucurbita moschata, storage time, vacuum packaging

\section{RESUMEN}

Calidad y cambios microbiológicos en calabaza mínimamente procesada y empacada en polietileno de baja densidad

${ }^{1}$ Manuscript submitted to Editorial Board 29 January 2016.

${ }^{2}$ This work was supported by the USDA National Institute of Food and Agriculture Hatch Program (accession numbers 227455 and 1000526), the Agricultural Experiment Station and the Faculty of Agricultural Sciences of the University of Puerto Rico, Mayagüez Campus.

${ }^{3}$ Ex-graduate Student, Food Science and Technology Program, University of Puerto Rico-Mayagüez Campus.

${ }^{4}$ Associate Professor, Food Science and Technology Program and Department of Agroenvironmental Sciences. University of Puerto Rico-Mayagüez Campus. Mayagüez, Puerto Rico, 00681 e-mail: rosa.chavez@upr.edu

${ }^{5}$ Professor, Department of Agroenvironmental Sciences. University of Puerto RicoMayagüez Campus. 
La calabaza (Cucurbita moschata) mínimamente procesada tiene un potencial considerable para crear nuevas oportunidades en el mercado de valor agregado en Puerto Rico. El objetivo de este trabajo fue evaluar la calidad y microbiología de la calabaza tropical mínimamente procesada empacada en bolsas de polietileno de baja densidad (LDPE, por sus siglas en inglés) y almacenada durante 20 días. Pedazos de $2 \mathrm{~cm}^{3}$ de dos cultivares de calabaza ('Taína Dorada' y 'Soler') fueron tratados por inmersión con una solución antimicrobiana que contenía ácido cítrico $(0.2 \%)$ y benzoato de sodio $(0.1 \%)$ durante $3 \mathrm{~min}$, centrifugados en una hilandera de ensaladas, empacados en bolsas de LDPE, sellados al vacío y sin vacío, y almacenados a $4^{\circ} \mathrm{C} \pm 2$ durante un período de 20 días. El tiempo de almacenamiento tuvo un efecto mínimo sobre las características químicas y físicas de los pedazos de calabaza. El contenido de $\mathrm{O}_{2}$ en los empaques sellados sin vacío disminuyó, mientras que el contenido de $\mathrm{CO}_{2}$ tuvo un incremento en las primeras 72 horas de almacenamiento. Los jurados del panel sensorial determinaron que la calabaza almacenada por 20 días mantiene una calidad aceptable. El producto mínimamente procesado tratado con una solución antimicrobial, empacado en bolsas de LDPE (selladas al vacío o sin vacío) y almacenado por 20 días a $4^{\circ} \mathrm{C} \pm 2$ presentó niveles microbiológicos seguros y una calidad aceptable por el consumidor.

Palabras clave: Cucurbita moschata, tiempo de almacenamiento, empaque al vacío

\section{INTRODUCTION}

Traditionally, fresh vegetables have been prepared by washing, cutting and peeling immediately or hours before serving. Many modern consumers are unwilling or unable to dedicate the time needed to prepare healthy and nutritious food despite being aware of the importance of consuming fruits and vegetables for their nutritional value. The demand for healthy, fresh and easy-to-prepare products has led to the development of a wide variety of minimally processed fruits and vegetables (Allende et al., 2006). According to the Global Agricultural Trade System (GATS) (USDA, 2014), in 2013, $\$ 2.33$ billion was generated in worldwide exports of processed vegetables, and that amount increased to $\$ 2.58$ billion in 2014 , an increase of $10.35 \%$.

Pumpkin species Cucurbita pepo, C. maxima and C. moschata are native to subtropical and tropical America, where they are used in a number of food dishes. Fruits of squash and pumpkin are rich in carotenoids, folate and vitamins $\mathrm{C}$ and $\mathrm{E}$, and are widely available throughout the year (Azevedo-Meleiro and Rodríguez-Amaya, 2007). In 2011 the top five pumpkin producing countries were: China with $6,905,000$ tons, India with 4,695,542 tons, Russia with $1,175,890$ tons, Iran with 951,253 tons and the U.S. with 814,330 tons (FAO, 2011). For fiscal year 2011, Puerto Rico produced a total value of $\$ 2.4$ million of tropical pumpkin (C. moschata). In Puerto Rico, pumpkin is traditionally used in preparing beans, with pumpkin pieces added to the sauce. But 
if pumpkin were sold already cut into pieces, its use would likely increase.

Minimum processing involves washing, removing inedible parts (skin, seeds, etc.), sanitizing, rinsing, drying and packaging. The goal is to reduce consumer labor and at the same time offer a ready-to-use product with a long shelf life, and unaltered nutritional value and sensory quality. The disadvantage of minimal processing is that produce is more susceptible to deterioration when fruit or vegetable tissue is cut into pieces. The biochemical changes that occur accelerate the decomposition process (Sgroppo and Sosa, 2009) and make these products more susceptible to microbial contamination due to the exposure of internal tissues (Sasaki, 2005). For this reason, conservation techniques such as low temperature storage and atmosphere modification techniques are used to extend shelf life and to slow down the deterioration of the sensory quality of minimally processed foods (Habibunnisa et al., 2001). Low temperatures and modified atmosphere reduce the proliferation of spoilage microorganisms and the kinetics of deterioration in a product (Rossaint et al., 2014). Another technique is the use of packaging materials that retard moisture loss and help maintain the quality of minimally processed fruits and vegetables (Schlimme, 1995).

Modified atmosphere packaging is based on modifying the composition of the atmosphere inside the package by reducing the amount of oxygen and replacing it with carbon dioxide and/or nitrogen (Ramos et al., 2013). Oxygen promotes deterioration reactions such as lipid oxidation and pigment darkening (Sandhya, 2009). Passive modified atmosphere packaging involves sealing packages under normal atmospheric conditions, without adding any gas (Tripathi et al., 2011).

Modified atmospheres with higher concentrations of $\mathrm{CO}_{2}$ and low concentrations of $\mathrm{O}_{2}$ reduce respiratory rates and minimize deterioration and physiological changes in plant tissues (Kader, 1986; Kader et al., 1989). The increase in plant tissue respiratory rate is due to high levels of ethylene (Brecht, 1995) induced by high temperatures or a wound in the tissue of the fruit or vegetable (Sasaki, 2005). When fruits or vegetables are cut into pieces for packaging, wounded tissue sets off a series of events. The packaged pieces will be exposed to greater amounts of ethylene, which in turn will increase respiration rate and lead to softening of fruit tissue and accelerated senescence (Ohlsson and Bengtsson, 2002). High concentrations of $\mathrm{CO}_{2}$ and low concentrations of $\mathrm{O}_{2}$ inhibit ethylene production in fruits and vegetables, delaying product ripening (Sasaki, 2005; Sandhya, 2009).

Plastic or polymer sheets are commonly used for controlling the atmosphere of a product and should have a selective permeability for gases (Oliveira et al., 2011). These sheets retard the rate of mois- 
ture loss, and some are used to minimize potential anaerobic conditions developed within the atmosphere packaging (Schlimme, 1995). One material commonly used is polyethylene (Gibe and Kim, 2013), especially low-density polyethylene (LDPE) (Ornelas-Paz et al., 2012). Other available materials are expanded polystyrene, polyvinyl chloride (PVC), polypropylene (PP) and polyethylene terephthalate (PET) (Oliveira et al., 2011). Polyethylene sheets have different degrees of permeability to water vapor and gases such as $\mathrm{CO}_{2}, \mathrm{O}_{2}$ and ethylene (Batista et al., 2007). LDPE is inexpensive and has high water vapor permeability (Oliveira et al., 2011). Use of appropriate packaging material and storage temperature can reduce the rate of respiration and inhibit spoilage microorganisms, extending the life of the product (Gibe and Kim, 2013).

Lack of proper temperature control during transportation, storage and marketing of fresh products may lead to deterioration due to increased metabolism of the product and microbial growth (Sandhya, 2009). Metabolic reactions in fruits and vegetables are reduced two to three times for each $10^{\circ} \mathrm{C}$ reduction in temperature (Brecht, 1995). Cooling minimally processed vegetables to 0 to $3^{\circ} \mathrm{C}$ can extend shelf life 5 to 18 days because of the reduction in respiratory rate (Watada et al., 1990). Maturation and ethylene production of fruit or vegetables increase when stored at high temperatures (Sandhya, 2009). Sasaki and colleagues (Sasaki, 2005; Sasaki et al., 2006) recommended that pumpkin (C. moschata) storage temperature should be between 1 and $5^{\circ} \mathrm{C}$. Habibunnisa and colleagues (2001) reported that minimally processed pumpkin (C. maxima) pieces may be stored for a period of 25 days at $5^{\circ} \mathrm{C} \pm 2$ in a package under modified atmosphere conditions while suffering a minimum weight loss $(0.06 \%)$.

Tropical pumpkin pieces preserved in a minimally processed form could promote increased consumption of this important and nutritious crop in Puerto Rico and other places. The objective of this research was to evaluate the effects of sealing methods (vacuum and non-vacuum) in bags of LDPE on the quality and microbiology of two cultivars of minimally processed tropical pumpkin stored for 20 days.

\section{MATERIALS AND METHODS}

The pumpkins used in this study were grown at the Lajas ('Taína Dorada') and Isabela ('Soler') Agricultural Experiment Stations of the University of Puerto Rico. After harvest, fruits were taken to the foodprocessing laboratory of the Food Science Technology Program of the University of Puerto Rico, Mayagüez Campus (UPRM). 


\section{Experimental design}

Separate experiments for each pumpkin cultivar were conducted as a randomized complete block design (RCB) with seven blocks (runs) and five storage/packaging treatments: (1) raw pumpkin (control, day 0 ), (2) vacuum sealed and evaluated at day 15, (3) vacuum sealed and evaluated at day 20, (4) non-vacuum sealed and evaluated at day 15 , and (5) non-vacuum sealed and evaluated at day 20.

\section{Minimal processing}

The first run (block) was carried out in August 2012, using a mature fruit of 'Taína Dorada'. The procedure was repeated in six additional runs from August to December 2012. Whole fruits were washed with water and soap, disinfected with a solution of sodium hypochlorite at $200 \mathrm{mg} / \mathrm{L}$ for three minutes and then rinsed again with clean water. Pumpkins were sliced, and the placenta and seeds were removed. Slices were peeled and cut into cubes of about $2 \mathrm{~cm}^{3}$. Cubes were immersed in an antimicrobial solution $(0.2 \%$ citric acid and $0.1 \%$ sodium benzoate) for approximately three minutes to prolong shelf life. They were then centrifuged in a salad spinner and dried with a disposable paper towel to remove excess water. A sample of $150 \mathrm{~g}$ (about seven to nine pieces) was placed in each of five LDPE bags. One bag of raw pieces was left unsealed and was used as the control (day 0 ). Two bags were vacuum-sealed and two bags were sealed without using vacuum. Vacuum and non-vacuum bags were stored for either 15 or 20 days, at $4^{\circ} \mathrm{C}$. The same procedure was used with 'Soler' from January to May 2013.

\section{Data collection}

Texture was measured by using a Texture Analyzer TA-XT2 (Stable Micro Systems Ltd., Godalming, Surrey, England) ${ }^{6}$. A 2-mm stainless steel probe measured the force required to penetrate pumpkin pieces. Five cubes from each sample bag (control, sealed under vacuum and without vacuum for 15 or 20 days) were taken for measurements of force in Newtons (N) of force. Color was measured using an EZ ColorFlex colorimeter (Hunter Associates Laboratory, Inc., Reston, Virginia) calibrated with black and white porcelain tiles. Color was measured on five cubes per sample as Hunter values $L^{*}$, $a^{*}$ and $b^{*}$, using illuminant D65; $L^{*}$ measures brightness or luminosity on a vertical axis where values range from 0 for black to 100 for white. The coordinates

\footnotetext{
${ }^{6}$ Company or trade names in this publication are used only to provide specific information. Mention of a company or trade name does not constitute an endorsement by the Agricultural Experiment Station of the University of Puerto Rico, nor is this mention a statement of preference over other equipment or materials.
} 
$\mathrm{a}^{*}$ and $\mathrm{b}^{*}$ locate the color of a sample on a rectangular-coordinate grid perpendicular to the $\mathrm{L}^{*}$ axis at the $\mathrm{L}^{*}$ position of the sample. The coordinate $\mathrm{a}^{*}$ measures the variation between red and green $(+\mathrm{a}=\mathrm{red},-\mathrm{a}=$ green), and $b^{*}$ is a measure of the variation between yellow and blue (+ $\mathrm{b}=$ yellow, $-\mathrm{b}=$ blue). The parameters $\mathrm{a}^{*}$ and $\mathrm{b}^{*}$ were used to calculate the chroma and hue angle of each pumpkin sample using the following formulas (McGuire, 1992):

\section{Chroma $=\sqrt{a^{2}+b^{2}}$}

Hue angle $=\tan ^{-1}(a / b)$

Chroma indicates the degree of departure from gray (at $\mathrm{L}^{*}$ axis) toward pure chromatic color. It is an index related to color saturation or intensity. Hue angle categorizes the type of color such as red, yellow, orange, etc. For pumpkin, hue should be in the range of 0 (orange) to 90 (yellow), with a value of 45 corresponding to an orange-yellow color. The $\mathrm{pH}$ was determined by a Docu-pH Meter (Sartorius Corporation, Bohemia, New York) with a digital potentiometer, by direct immersion

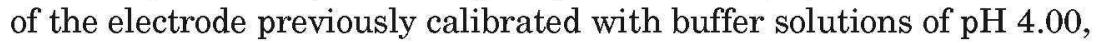
7.00 and 10.00 . The $\mathrm{pH}$ and total soluble solids were obtained from the supernatant of pieces of pumpkins that were crushed in a coffee bean grinder Model Cuisinart DCG-20N (Cuisinart Inc., East Windsor, New Jersey) and then centrifuged (Damon/ IEC Model HN-SII Thermo IEC, Needham Heights, Massachusetts). Total soluble solids were determined as degree Brix ( $\left.{ }^{\circ} \mathrm{Brix}\right)$ using a hand refractometer. Titratable acidity was measured with a $0.10 \mathrm{~N} \mathrm{NaOH}$ solution and phenolphthalein as an indicator according to the AOAC 942.15 method (Horwitz and AOAC International, 2003). Results were expressed as a percentage of citric acid.

The percentages of $\mathrm{O}_{2}$ and $\mathrm{CO}_{2}$ gases were measured inside the nonvacuum sealed bags after 24, 48 and 72 hours, using the MiniFoodPack Servomex gas analyzer (5200) (Servomex Company Inc., Brighton, East Sussex, United Kingdom). Bags were pierced with a needle, which sucked out the air inside the packaging for nine seconds.

The microbiological analysis was performed in duplicate for aerobic coliforms/ Escherichia coli, lactic acid bacteria, Staphylococcus aure$u s$, molds and yeasts. These procedures were carried out according to protocols established by the Bacteriological Analytical Manual (BAM) (Food and Drug Administration Services, 2001). A 25 g sample was taken from each bag and homogenized with $225 \mathrm{~mL}$ of $0.1 \%$ peptone water in the Stomacher 400 Laboratory Blender (Seward Laboratory Systems Inc., Davie, Florida, USA) for two minutes. Serial dilution samples $\left(1 \mathrm{~mL}\right.$ ), from $10^{-1}$ to $10^{-6}$, were plated on MRS agar (De Man 
et al., 1960) to determine lactic acid bacteria (incubated at $35^{\circ} \mathrm{C} \pm$ 1 for $24 \mathrm{~h} \pm 2$ ) and on $3 \mathrm{M}^{\mathrm{TM}}$ Petrifilm ${ }^{\mathrm{TM}}$ plates to determine aerobic bacteria (incubated at $35^{\circ} \mathrm{C} \pm 1$ for $48 \mathrm{~h} \pm 3$ ), coliforms/Escherichia coli (incubated at $35^{\circ} \mathrm{C} \pm 1$ for $24 \mathrm{~h} \pm 2$ ), Staphylococcus aureus (incubated at $35^{\circ} \mathrm{C} \pm 1$ for $24 \mathrm{~h} \pm 2$ ), and molds and yeasts (incubated at $25^{\circ} \mathrm{C} \pm 1$ for 3 to $5 \mathrm{~d}$ ). Observations were recorded and results were expressed as colony forming units (CFU) per gram, then converted to log units.

To determine the composition of unprocessed pumpkin samples, a proximal analysis was carried out on a separate fruit of 'Taína Dorada' and 'Soler.' Methods described by AOAC (Association of Official Analytical Chemists) (Horwitz and AOAC International, 2003) were used to determine the following analyses: AOAC 966.02 for determining moisture, AOAC 923.03 for ash content, and AOAC 991.20 for protein content (using the Kjeldahl method with a conversion factor =6.25). Crude fat and crude fiber Am5-04 Ba 6-05 were determined according to the official methods described by AOCS (2005) (American Oil Chemists' Society). Total carbohydrate was what remained after subtracting total fat, protein, moisture and ash values.

A sensory evaluation for general taste was performed to determine the acceptability of tropical pumpkin 'Taína Dorada' and 'Soler' that was minimally processed as previously described, and either immediately tested (control treatment) or packed under vacuum and nonvacuum and stored for 20 days. Pumpkin pieces were steamed in a medium size pot with $120 \mathrm{ml}$ of water and $1 \mathrm{~g}$ of salt for 10 minutes. The evaluation was conducted by a panel of 30 students and employees of the Science and Food Technology of UPRM who were frequent consumers of pumpkin. A 7-point hedonic scale $(1=$ extremely dislike; $2=$ dislike very much; $3=$ dislike; $4=$ neither like nor dislike; $5=$ like; $6=$ like very much; 7 = extremely like) was used following suggestions by Meilgaard et al. (2007).

\section{Statistical analysis}

All data except that from the proximal analyses was analyzed by analysis of variance using the statistical package InfoStat (version 2012e, Di Rienzo et al., 2012). Orthogonal contrasts $(\alpha=0.05)$ were used to compare means of (1) control versus the average of vacuum and non-vacuum at 15 and 20 days of storage, (2) vacuum versus nonvacuum packaging, and (3) 15 versus 20 days of storage. A Tukey's test $(\alpha=0.05)$ was used to compare means of percentage of $\mathrm{O}_{2}$ and $\mathrm{CO}_{2}$. In the proximal analyses, the three determinations made for protein, fat, ash, fiber and total carbohydrates (proximal analyses) were averaged and the standard deviation was determined. 


\section{RESULTS AND DISCUSSION}

\section{Physical and Chemical Analyses}

At the beginning of the storage period (day 0), firmness of pumpkin pieces was $8.06 \mathrm{~N}$ for 'Taína Dorada', $10.40 \mathrm{~N}$ for 'Soler' (Table 1). For 'Taína Dorada', there were no significant changes throughout the 20day storage period, but average firmness was significantly higher in the non-vacuum packed treatments $(7.74 \mathrm{~N})$ compared with vacuumpacked treatments $(7.51 \mathrm{~N})$. Neither the vacuum nor the non-vacuum packed 'Soler' pumpkins showed significant changes during the 20-day storage period. Firmness indicates if there are changes in the structure and cohesion of cells and if biochemical alterations have occurred that impact the texture of the product (Alvés et al., 2010a). Alvés and colleagues (2010a) reported an average firmness of $4.86 \mathrm{~N}$ in C. moschata. In a study by Habibunnisa and colleagues (2001), firmness of pumpkin pieces packaged under various modified atmosphere treatments and stored at $5^{\circ} \mathrm{C} \pm 2$ for 25 days in LDPE bags decreased $16.9 \%$. Factors such as temperature and composition of the atmosphere inside the packaging affect the firmness of the plant tissue. High concentrations of ethylene, which is induced by high temperature or the presence of a wound in the tissue of the fruit or vegetable, leads to softening of plant tissue (Ohlsson and Bengtsson, 2002; Sasaki, 2005). Since low $\mathrm{O}_{2}$ and high $\mathrm{CO}_{2}$ concentrations reduce ethylene production, packaging that maintains these relative concentrations aid in the maintenance of a stable firmness during 20 days of storage.

Type of packaging and storage period had no effect on chroma of pumpkin pieces in either of the two cultivars, and luminosity $\left(\mathrm{L}^{*}\right)$ and hue angle were only minimally affected by these treatments (Table 1). In 'Taína Dorada', average luminosity of vacuum-packed pieces was significantly lower $\left(L^{*}=64.78\right)$ than in non-vacuum packed pumpkin $\left(\mathrm{L}^{*}=65.78\right)$. In 'Soler', the mean for hue was higher for raw pumpkin at day $0(67.42)$ than for treated (vacuum or non-vacuum at 15 or 20 days) pumpkin pieces (66.07). In a previous study, raw pieces of 'Taína Dorada' [designated "PRShortline1" in Wessel-Beaver et al. (2006)] had an intense orange color with hue averaging 65.6 and chroma averaging 74.2. In the same study, 'Soler' tended to be more yellow (average hue $=68.0$ ) with a slightly more saturated color (chroma $=75.0$ ). Color of fruits or vegetables that have undergone minimum processing tends to be affected due to processes such as peeling and chopping. Discoloration occurs when the damaged tissue is scarred after such operations (Angós et al., 2008). The use of a sharp stainless steel knife for chopping followed by immediate cooling of cut pieces are factors that aid in maintaining color stability (Allende et al., 2006; Parzanese, 
TABLE 1.-Mean of physical-chemical analysis values of tropical pumpkin cultivars Taina Dorada and Soler minimally processed, vacuum and non-vacuum packed and stored for 15 and 20 days at $4^{\circ} \mathrm{C} \pm 2$.

\begin{tabular}{|c|c|c|c|c|c|c|c|c|}
\hline Cultivar & Treatment & $\begin{array}{l}\text { Firmness } \\
(\mathrm{N})\end{array}$ & $\begin{array}{l}\text { Luminosity } \\
\left(\mathrm{L}^{*}\right)\end{array}$ & $\begin{array}{c}\text { Hue } \\
\text { angle }\end{array}$ & Chroma & $\mathrm{pH}$ & ${ }^{\circ} \mathrm{Brix}$ & Acidity $(\%)$ \\
\hline \multirow[t]{14}{*}{ 'Taína Dorada' } & Control, day 0 (raw pumpkin) & 8.06 & 65.73 & 64.84 & 79.15 & 6.70 & 7.24 & 0.04 \\
\hline & Vacuum packed for 15 days & 8.06 & 65.29 & 64.90 & 81.98 & 6.99 & 7.14 & 0.04 \\
\hline & Non-vacuum packed for 15 days & 8.30 & 65.79 & 64.32 & 80.20 & 6.99 & 7.22 & 0.04 \\
\hline & Vacuum packed for 20 days & 6.96 & 64.28 & 64.68 & 80.56 & 6.96 & 7.04 & 0.04 \\
\hline & Non-vacuum packed for 20 days & 7.17 & 65.77 & 64.84 & 78.28 & 7.05 & 7.15 & 0.04 \\
\hline & $F$ test & $\mathrm{ns}$ & $\mathrm{ns}$ & $\mathrm{ns}$ & $\mathrm{ns}$ & $\mathrm{ns}$ & $\mathrm{ns}$ & $\mathrm{ns}$ \\
\hline & $\mathrm{CV}(\%)$ & 9.64 & 1.90 & 1.36 & 3.85 & 2.06 & 4.08 & 25.70 \\
\hline & $\mathrm{SD}$ & 0.74 & 1.24 & 0.88 & 3.08 & 0.14 & 0.30 & 0.01 \\
\hline & Orthogonal Contrasts & & & & & & & \\
\hline & Control vs. other treatments & ns & $\mathrm{ns}$ & ns & ns & $*$ & $\mathrm{~ns}$ & ns \\
\hline & Vacuum vs. non-vacuum & $*$ & $*$ & $\mathrm{~ns}$ & ns & $\mathrm{ns}$ & ns & $\mathrm{ns}$ \\
\hline & 15 vs. 20 days & ns & $\mathrm{ns}$ & $\mathrm{ns}$ & $\mathrm{ns}$ & $\mathrm{ns}$ & $\mathrm{ns}$ & $\mathrm{ns}$ \\
\hline & $\begin{array}{l}\text { Packaging type } \mathrm{x} \text { number of } \\
\text { days stored (interaction) }\end{array}$ & ns & $\mathrm{ns}$ & $\mathrm{ns}$ & $\mathrm{ns}$ & $\mathrm{ns}$ & $\mathrm{ns}$ & $\mathrm{ns}$ \\
\hline & $\begin{array}{l}\text { Packaging type } x \text { number of } \\
\text { days stored (interaction) }\end{array}$ & ns & ns & $\mathrm{ns}$ & ns & ns & ns & ns \\
\hline
\end{tabular}


TABLE 1.-(Continued) Mean of physical-chemical analysis values of tropical pumpkin cultivars Taina Dorada and Soler minimally processed, vacuum and non-vacuum packed and stored for 15 and 20 days at $4^{\circ} \mathrm{C} \pm 2$.

\begin{tabular}{|c|c|c|c|c|c|c|c|c|}
\hline Cultivar & Treatment & $\begin{array}{l}\text { Firmness } \\
(\mathrm{N})\end{array}$ & $\begin{array}{c}\text { Luminosity } \\
\left(\mathrm{L}^{*}\right)\end{array}$ & $\begin{array}{c}\text { Hue } \\
\text { angle }\end{array}$ & Chroma & $\mathrm{pH}$ & ${ }^{\circ}$ Brix & Acidity $(\%)$ \\
\hline \multirow[t]{12}{*}{ 'Soler' } & $\begin{array}{l}\text { Control, day } 0 \text { (raw pumpkin) } \\
\text { Vacuum packed for } 15 \text { days }\end{array}$ & $\begin{array}{l}10.40 \\
10.61\end{array}$ & $\begin{array}{l}64.60 \\
64.48\end{array}$ & $\begin{array}{l}67.42 \\
66.15\end{array}$ & $\begin{array}{l}78.61 \\
78.29\end{array}$ & $\begin{array}{l}6.82 \\
7.02\end{array}$ & $\begin{array}{l}9.37 \\
9.32\end{array}$ & $\begin{array}{l}0.03 \\
0.02\end{array}$ \\
\hline & Non-vacuum packed for 15 days & 10.54 & 64.89 & 66.45 & 77.66 & 7.09 & 9.49 & 0.02 \\
\hline & Vacuum packed for 20 days & 10.14 & 63.88 & 65.83 & 79.01 & 7.04 & 9.25 & 0.02 \\
\hline & Non-vacuum packed for 20 days & 10.68 & 63.71 & 65.83 & 77.97 & 7.14 & 9.51 & 0.02 \\
\hline & F test & ns & $\mathrm{ns}$ & $\mathrm{ns}$ & $\mathrm{ns}$ & $\mathrm{ns}$ & $\mathrm{ns}$ & ns \\
\hline & $\mathrm{CV}(\%)$ & 6.07 & 1.69 & 1.06 & 1.90 & 1.96 & 3.26 & 34.32 \\
\hline & $\mathrm{SD}$ & 0.63 & 1.09 & 0.70 & 1.49 & 0.14 & 0.30 & 0.01 \\
\hline & Orthogonal Contrasts & & & & & & & \\
\hline & Control vs. other treatments & $\mathrm{ns}$ & $\mathrm{ns}$ & $*$ & $\mathrm{~ns}$ & * & $\mathrm{ns}$ & * \\
\hline & Vacuum vs. non-vacuum & $\mathrm{ns}$ & $\mathrm{ns}$ & ns & $\mathrm{ns}$ & $\mathrm{ns}$ & ns & ns \\
\hline & 15 vs. 20 days & $\mathrm{ns}$ & * & $\mathrm{ns}$ & $\mathrm{ns}$ & $\mathrm{ns}$ & $\mathrm{ns}$ & ns \\
\hline & $\begin{array}{l}\text { Packaging type } \mathrm{x} \text { number of } \\
\text { days stored (interaction) }\end{array}$ & $\mathrm{ns}$ & $\mathrm{ns}$ & $\mathrm{ns}$ & ns & $\mathrm{ns}$ & $\mathrm{ns}$ & ns \\
\hline
\end{tabular}

${ }^{*}=$ significant and $\mathrm{ns}=$ nonsignificant, respectively, at the $\mathrm{p}=0.05$ probability level 
2014). These protocols minimize physical damage and the deterioration process.

Raw pieces of both 'Taína Dorada' and 'Soler' had significantly lower $\mathrm{pH}$ values than pieces packaged and stored for either 15 or 20 days (Table 1). Type of packaging and length of storage period (15 versus 20 days) had no effect on $\mathrm{pH}$. The increase in $\mathrm{pH}$ during storage may be related to the uptake of organic acids by the respiration process (Alvés et al., 2010b). Certain molds and yeasts have the ability to use organic acids, reducing acidity, increasing $\mathrm{pH}$, and creating a favorable environment for the proliferation of pathogenic bacteria (Beuchat, 2002). In general, fruits and vegetables are rich in carbohydrates, low in protein, and have a neutral $\mathrm{pH}$ and high water activity, thus making them vulnerable to microbial growth (Ramos et al., 2013). It has been shown that the $\mathrm{pH}$ value of pumpkin ranges from 6.11 to 6.77 (Alvés et al., 2010b; Jacobo-Valenzuela et al., 2011). Sgroppo and Sosa (2009) reported $\mathrm{pH}$ values of 7.01 to 7.07 in stored pieces of $C$. moschata.

Total soluble solids ( ${ }^{\circ}$ Brix) were unaffected by type of packaging or length of storage period (Table 1). The ${ }^{\circ}$ Brix ranged from 7.04 to 7.24 for 'Taína Dorada' and from 9.25 to 9.51 for 'Soler.' Type of packaging had no effect on acidity. However, raw pieces of 'Soler' had a significantly higher percentage of acidity compared with stored pieces. A review of the literature shows variable estimates of soluble solids in pumpkin. This is likely due, in part, to the testing of various species (three different species are commonly referred to as "pumpkin" or "squash"). Within the genus Cucurbita cultivar differences are also known to occur among genotypes (L. Wessel-Beaver, personal communication). Jacobo-Valenzuela and colleagues (2011) reported a ${ }^{\circ}$ Brix of 6.42 in pumpkin (C. moschata species). Wessel-Beaver (2013) reported a 'Brix of 10.75 and 5.35 for 'Taína Dorada' and 'Soler,' respectively, values that appear to be in complete contrast to the current study where 'Soler' was observed to have high amounts of soluble solids. In general, the experience of Wessel-Beaver has been that 'Taína Dorada' generally has higher concentrations of soluble solids compared with 'Soler'. Why our current study had different results is not clear.

Habibunnisa and colleagues (2001) reported that at 25 days of storage the average ${ }^{\circ}$ Brix of pumpkins in non-vacuum packaging in LDPE was 7.91 while vacuum packaging was $8.52^{\circ}$ Brix. Silva and colleagues (2009) reported concentrations of soluble solids between 9.83 and $10.38^{\circ} \mathrm{Brix}$ in minimally processed pumpkin packed in bags of polyvinyl chloride (PVC) and stored at 5 and $10^{\circ} \mathrm{C}$ for 12 days, respectively. The content of soluble solids in pumpkin is an important quality parameter because they are characterized by high sugar content (Gibe and Kim, 2013). Sugars represent a large part of the soluble solids (85 
to $90 \%$ ) found in most fruits, the rest consisting of vitamins, phenolic compounds, organic acids and pectin (Alvés et al., 2010b).

The percentage of $\mathrm{O}_{2}$ and $\mathrm{CO}_{2}$ in the atmosphere within the nonvacuum packaging was measured for 72 hours after processing. In 'Taína Dorada,' the amount of $\mathrm{O}_{2}$ present in LDPE bags decreased between 24 and 72 hours (Table 2). A similar trend was observed for 'Soler,' although the decrease in $\mathrm{O}_{2}$ was not significant. The opposite occurred for $\mathrm{CO}_{2}$ content; the percentage of $\mathrm{CO}_{2}$ increased significantly between 24 and 72 hours. In general, the coefficients of variation (CV) were much higher for these variables compared with those of other variables measured in this experiment. The increased levels of $\mathrm{CO}_{2}$ and reduced $\mathrm{O}_{2}$ is associated with the stress caused by the minimum processing as the tissues are damaged due to mechanical manipulations. This stress promotes metabolic disorders such as ethylene production, accumulation of secondary metabolites and cell disruption (Alvés et al., 2010a). Glycolysis, the tricarboxylic acid cycle and the electron transport system are the metabolic pathways of aerobic respiration, which involves breaking down organic reserves such as carbohydrates, lipids and organic acids to simple molecules (Fonseca et al., 2002). This process results in the consumption of $\mathrm{O}_{2}$ in a series of enzymatic reactions during the process. In a study by Habibunnisa and colleagues (2001), LDPE bags packed with pieces of minimally processed pumpkins and stored at $5^{\circ} \mathrm{C}$ had a mean percentage of $\mathrm{O}_{2}$ of $2 \%$ at 60 hours while $\mathrm{CO}_{2}$ was at $15 \%$. The benefits of having a high content of $\mathrm{CO}_{2}$ in a modified atmosphere are associated with inhibition of psychotropic spoilage microorganisms (Soliva-Fortuny et al., 2004).

TABLE 2.-Percentage of $\mathrm{O}_{2}$ and $\mathrm{CO}_{2}$ in non-vacuum sealed bags of minimally processed pieces of tropical pumpkin Taina Dorada and Soler 24 to 72 hours after storage at $4^{\circ} \mathrm{C}$.

\begin{tabular}{lccc}
\hline Cultivar & $\begin{array}{c}\text { Storage time } \\
\text { (hours) }\end{array}$ & $\begin{array}{c}\mathrm{O}_{2} \\
(\%)\end{array}$ & $\begin{array}{c}\mathrm{CO}_{2} \\
(\%)\end{array}$ \\
\hline Taína Dorada & 24 & $12.44 \mathrm{a}$ & $3.61 \mathrm{c}$ \\
Taína Dorada & 48 & $6.49 \mathrm{ab}$ & $6.09 \mathrm{bc}$ \\
Taína Dorada & 72 & $3.54 \mathrm{~b}$ & $10.06 \mathrm{ab}$ \\
Soler & 24 & $6.46 \mathrm{ab}$ & $4.73 \mathrm{c}$ \\
Soler & 48 & $2.11 \mathrm{~b}$ & $9.26 \mathrm{ab}$ \\
Soler & 72 & $0.80 \mathrm{~b}$ & $13.39 \mathrm{a}$ \\
LSD & & 6.02 & 4.18 \\
CV $(\%)$ & 69.8 & 32.8 \\
\hline
\end{tabular}

Within the same column, means with a common letter are not significantly different at $p=0.05$ according to Tukey's test.

$\mathrm{LSD}=$ Tukey's least significant difference at $\mathrm{p}=0.05$. 
TABLE 3.-Counts of aerobic bacteria and molds and yeast in tropical pumpkin Taina Dorada' and 'Soler', minimally processed, vacuum and non-vacuum packaged, stored for 15 and 20 days at $4^{\circ} \mathrm{C} \pm 2$.

\begin{tabular}{|c|c|c|c|}
\hline Cultivar & Treatment & $\begin{array}{c}\text { Aerobic } \\
\text { bacteria } \\
(\log \text { CFU/g })^{1}\end{array}$ & $\begin{array}{c}\text { Molds } \\
\text { and yeast } \\
\text { (log CFU/g) }\end{array}$ \\
\hline \multirow[t]{13}{*}{ 'Taína Dorada' } & Control, day 0 (raw pumpkin) & 3.15 & 2.3 \\
\hline & Vacuum packed for 15 days & 3.71 & 2.4 \\
\hline & Non-vacuum packed for 15 days & 4.37 & 2.3 \\
\hline & Vacuum packed for 20 days & 4.09 & 2.6 \\
\hline & Non-vacuum packed for 20 days & 4,44 & 2.7 \\
\hline & $F$ test & $\mathrm{NS}^{2}$ & NS \\
\hline & $\mathrm{CV}(\%)$ & 21.45 & 7.78 \\
\hline & $\mathrm{SD}$ & 0.85 & 0.17 \\
\hline & Orthogonal Contrasts & & \\
\hline & Control vs. other treatments & $*$ & NS \\
\hline & Vacuum vs. non-vacuum & NS & NS \\
\hline & 15 vs. 20 days & NS & NS \\
\hline & $\begin{array}{l}\text { Packaging type } \mathrm{x} \text { number of } \\
\text { days stored (interaction) }\end{array}$ & NS & NS \\
\hline \multirow[t]{12}{*}{ 'Soler' } & Control, day 0 (raw pumpkin) & 2.90 & 2.3 \\
\hline & $\begin{array}{l}\text { Vacuum packed for } 15 \text { days } \\
\text { Non-vacuum packed for } 15 \text { days }\end{array}$ & $\begin{array}{l}3.11 \\
3.07\end{array}$ & 2.4 \\
\hline & Vacuum packed for 20 days & 2.76 & 2.7 \\
\hline & Non-vacuum packed for 20 days & 2.96 & 2.9 \\
\hline & F test & NS & NS \\
\hline & $\mathrm{CV}(\%)$ & 15.39 & 11.42 \\
\hline & $\mathrm{SD}$ & 0.46 & 0.26 \\
\hline & Orthogonal Contrasts & & \\
\hline & Control vs. other treatments & NS & NS \\
\hline & Vacuum vs. non-vacuum & NS & NS \\
\hline & 15 vs. 20 days & NS & NS \\
\hline & $\begin{array}{l}\text { Packaging type } \mathrm{x} \text { number of } \\
\text { days stored (interaction) }\end{array}$ & NS & NS \\
\hline
\end{tabular}

${ }^{1} \mathrm{CFU}=$ colony forming units

${ }^{2} \mathrm{NS}=$ non significant at $\mathrm{p}=0.05$

\section{Microbiological analysis}

No Escherichia coli, coliforms, Staphylococcus aureus nor Lactobacillus spp. were detected in vacuum or non-vacuum packaged pumpkin pieces sampled after 15 and 20 days of storage (data not shown). Aerobic bacteria, and mold and yeast counts were also generally unaffected by the type of packaging with the exception of a lower aerobic bacteria count in raw pieces of 'Taína Dorada' compared with stored pieces. 
Aerobic bacteria counts ranged from 2.76 to 4.44 log CFU/g while mold and yeast counts ranged from 2.19 to $2.41 \mathrm{log}$ CFU/g.

While total counts of bacteria in vegetables are used as parameters of the microbial load, these counts do not indicate whether the population has a beneficial or harmful effect (Alvés et al., 2010b). The counts give an idea of the quality of the product. Roura and colleagues (2004), obtained populations of mesophilic aerobic microorganisms of $8.50 \mathrm{log}$ CFU/g ( $\left.3.50 \times 10^{8} \mathrm{CFU} / \mathrm{g}\right)$ at day 15 in minimally processed pumpkin pieces, packed in plastic polyethylene containers and then stored at 10 to $12^{\circ} \mathrm{C}$. Sasaki and colleagues (2006) conducted a study in which diced pumpkins chilled to $5^{\circ} \mathrm{C}$ exhibited an aerobic bacteria count of $0.60(4.00 \times 10 \mathrm{CFU} / \mathrm{g}), 5.50\left(3.40 \times 10^{5} \mathrm{CFU} / \mathrm{g}\right)$ and $6.90 \mathrm{log} \mathrm{CFU} / \mathrm{g}$ ( $7.50 \times 10^{6} \mathrm{CFU} / \mathrm{g}$ ) on days 0,6 and 12 , respectively. Habibunnisa and colleagues (2001) applied a $0.2 \%$ solution of citric acid and $0.1 \%$ potassium metabisulfite to diced pumpkins and obtained a count of aerobic bacteria of $5.50 \log \mathrm{CFU} / \mathrm{g}\left(32.40 \times 10^{4} \mathrm{CFU} / \mathrm{g}\right)$ at day 25 when stored at $5^{\circ} \mathrm{C}$. Roura and colleagues (2004) obtained values on molds and yeasts of $6.80 \mathrm{log} \mathrm{CFU} / \mathrm{g}$ and $6.30 \times 10^{6} \mathrm{CFU} / \mathrm{g}$ at day $15 \mathrm{in}$ pieces of minimally processed pumpkins, wrapped in polyethylene and then stored at 10 to $12^{\circ} \mathrm{C}$ in plastic containers. Food spoilage by yeast is the result of fermentation activity, while mold spoilage is due to the structural degradation of polysaccharides being reduced to simple sugars for use as an energy source (Beuchat, 2002).

\section{Proximal analysis}

In general, pumpkin has high moisture content, is low in fat and is an excellent source of vitamins, minerals and dietary fiber (Alvés et al., 2010b). The chemical composition of pumpkins 'Taína Dorada' and 'Soler' was not affected by storage period or the type of packaging (Table 4). The values obtained in chemical composition are similar to those reported by Alvés and colleagues (2010b) and Jacobo-Valenzuela and colleagues (2011) for C. moschata.

\section{Sensory evaluation}

The acceptability of 'Taína Dorada' and 'Soler' in two types of packaging were evaluated using a 7-point hedonic scale. Evaluations were done on day 0 and 20 of storage (Table 4). 'Taína Dorada' scored 5.73 on day 0 , and 5.23 and 5.67 in vacuum and non-vacuum packaging, respectively, at day 20 . 'Soler' scored 5.53 on day 0 , and 5.20 and 5.80 in vacuum and non-vacuum packaging, respectively, on day 20 . These averages indicate that acceptability was between "like" and "like very much." Number of days of storage and type of packaging did not influence the taste of minimally processed tropical pumpkins. The appear- 
TABLE 4.-Chemical composition and acceptability of pieces of minimally processed, tropical pumpkin 'Taina Dorada' and 'Soler' at day 0 (raw) and stored for 20 days at $4^{\circ} \mathrm{C}$ in vacuum and non-vacuum low-density polyethylene packaging.

\begin{tabular}{|c|c|c|c|c|c|c|c|}
\hline \multirow[b]{2}{*}{ Cultivar } & \multicolumn{7}{|c|}{ Proximal analyses $^{1}$} \\
\hline & Treatment & Protein $(\%)$ & Fat $(\%)$ & $\operatorname{Ash}(\%)$ & Fiber $(\%)$ & $\begin{array}{c}\text { Total } \\
\text { carbohydrates }(\%)\end{array}$ & Acceptance \\
\hline \multirow[t]{3}{*}{ 'Taína Dorada' } & Control, day 0 & $1.21 \pm 0.25$ & $0.10 \pm 0.05$ & $0.52 \pm 0.12$ & $0.72 \pm 0.10$ & 4.44 & $5.73 \mathrm{a}$ \\
\hline & Vacuum, day 20 & $1.41 \pm 0.13$ & $0.08 \pm 0.01$ & $0.61 \pm 0.03$ & $0.67 \pm 0.02$ & 4.23 & $5.23 \mathrm{a}$ \\
\hline & Non-vacuum, day 20 & $1.42 \pm 0.19$ & $0.09 \pm 0.01$ & $0.66 \pm 0.01$ & $0.71 \pm 0.06$ & 4.11 & $5.67 \mathrm{a}$ \\
\hline \multirow[t]{2}{*}{ 'Soler' } & $\begin{array}{l}\text { Control, day } 0 \\
\text { Vacuum, day } 20\end{array}$ & $\begin{array}{l}0.91 \pm 0.07 \\
0.90 \pm 0.03\end{array}$ & $\begin{array}{l}0.14 \pm 0.05 \\
0.10 \pm 0.02\end{array}$ & $\begin{array}{l}0.79 \pm 0.05 \\
0.79 \pm 0.02\end{array}$ & $\begin{array}{l}0.97 \pm 0.28 \\
0.88 \pm 0.08\end{array}$ & $\begin{array}{l}4.19 \\
4.32\end{array}$ & $\begin{array}{l}5.53 \mathrm{a} \\
5.20 \mathrm{a}\end{array}$ \\
\hline & Non-vacuum, day 20 & $0.91 \pm 0.05$ & $0.09 \pm 0.01$ & $0.74 \pm 0.02$ & $0.89 \pm 0.11$ & 4.36 & $5.80 \mathrm{a}$ \\
\hline Tukey $(0.05)^{3}$ & & & & & & & 0.53 \\
\hline
\end{tabular}

${ }^{1}$ Proximal analysis is reported as the mean of three determinations \pm standard deviation.

${ }^{2}$ Acceptance was measured on a 7 -point scale where $1=$ extremely dislike to $7=$ extremely like

${ }^{3}$ Tukey $(0.05)=$ Tukey's Least Significant Difference at $\mathrm{p}=0.05$. In the same column, means followed by the same letter are not different at $\mathrm{p}=0.05$. 
ance of cut fresh vegetables is the first attribute perceived by consumers and strongly affects their purchase decision (Alvés et al., 2010b). Habibunnisa and colleagues (2001) reported that pieces of pumpkins that were treated and packed in LDPE bags stored at $5^{\circ} \mathrm{C} \pm 2$ remained in good condition for 25 days, retaining the look of freshness, color and flavor.

\section{CONCLUSION}

Minimally processed pumpkin pieces treated with an antimicrobial solution containing $0.2 \%$ citric acid and $0.1 \%$ sodium benzoate, packed in low-density polyethylene bags (vacuum and non-vacuum) and stored at $4^{\circ} \mathrm{C} \pm 2$ exhibited very few physical or chemical changes over a 20 day storage period, maintained safe levels of microbes and acceptable quality as judged by consumers.

\section{LITERATURE CITED}

Allende, A., F. Tomás-Barberán and M. Gil, 2006. Minimal processing for healthy traditional foods. Trends in Food Science \& Technology 17: 513-519.

Alvés, J. A., E. V. Vilas Boas, B. M. Vilas Boas, E. C. Souza and R. Hilsdorf, 2010a. Vida útil de produto minimamente processado composto por abóbora, cenoura, chuchu e mandioquinha-salsa. Ciência e Agrotecnologia 34(1): 182-189.

Alvés, J. A., E. V. Vilas Boas, B. M. Vilas Boas and E. C. Souza, 2010b. Qualidade de produto minimamente processado à base de abóbora, cenoura, chuchu e mandioquinha-salsa. Ciência e Tecnologia Alimentos 30(3): 625-634.

Angós, I., P. Vírseda and T. Fernández, 2008. Control of respiration and color modification on minimally processed potatoes by means of low and high $\mathrm{O}_{2} / \mathrm{CO}_{2}$ atmospheres. Postharvest Biology and Technology 48: 422-430.

Azevedo-Meleiro, C. H. and D. B. Rodríguez-Amaya, 2007. Qualitative and quantitative differences in carotenoid composition among Cucurbita moschata, Cucurbita maxima, and Cucurbita pepo. Journal of Agricultural and Food Chemistry 55: 4027-4033.

Batista, P., A. O dos Santos, M. Pires, B. Dantas and A. Rosa, 2007. Utilização de filmes plásticos e comestíveis na conservação pós-colheita de melão amarelo. Horticultura. Brasileira 25(4): 572-576.

Beuchat, L. R., 2002. Ecological factors influencing survival and growth of human pathogens on raw fruits and vegetables. Microbes and Infection 4: 413-423.

Brecht, J. K., 1995. Physiology of lightly processed fruits and vegetables. HortScience 30 (1): 18-24.

De Man, J. D., R. Rogosa and M. E. Sharpe, 1960. A medium for the cultivation of lactobacilli. J Appl Bact 23: 130-135.

Di Rienzo, J. A., F. Casanoves, M. G. Balzarini, L. González, M. Tablada and C. W. Robledo, 2012. InfoStat version 2012e. Grupo InfoStat FCA: Universidad Nacional de Córdoba, Argentina. Available at: http://www.infostat.com.ar/

FAO, 2011. FAOSTAT. Retrieved: November 20, 2013. Available at: http://faostat.fao.org/ site/339/default.aspx

Fonseca, S., F. Oliveira and J. Brecht, 2002. Modeling respiration rate of fresh fruits and vegetables for modified atmosphere packages: A review. Journal of Food Engineering 52: 99-119.

Food and Drug Administration Services, 2001. Laboratory Methods - BAM: Aerobic plate count. Retrieved: November 19, 2013. Available at: http://www.fda.gov/Food/FoodScienceResearch/LaboratoryMethods/ucm063346.htm 
Gibe, A. and J. Kim, 2013. Influence of cutting size and packaging materials on the quality of fresh-cut winter squash (var. Ajijimang). Agricultural Science 4(9): 477482.

Habibunnisa, R. Baskaran, R. Prasad and K. M. Shivaiah, 2001. Storage behavior of minimally processed pumpkin (Curcubita maxima) under modified atmosphere packaging conditions. European Food Research and Technology 212(2): 165-169.

Horwitz, W. and AOAC International, 2003. Official Methods of Analysis of the AOAC International ( $17^{\text {th }}$ ed.). Gaithersburg: AOAC International.

Jacobo-Valenzuela, N., J. J. Zazueta-Morales, J. A. Gallegos-Infante, F. Aguilar-Gutierrez, I. L. Camacho-Hernández, N. E. Rocha-Guzmán and R. F. González-Laredo, 2011. Chemical and physicochemical characterization of winter squash (Cucurbita moschata D.). Notulae Botanicae Horti Agrobotanici Cluj. 39(1): 34-40.

Kader, A. A., 1986. Biochemical and physiological basis for effects of controlled and modified atmospheres on fruits and vegetables. Food Technol 40: 99-104.

Kader A. A., E. L. Zagory and E. L. Kerbel, 1989. Modified atmosphere packaging of fruit and vegetables. Critical Reviews in Food Science and Nutrition 28: 1-30.

McGuire, R., 1992. Reporting of objective color measurements. HortScience 27(12): 12541255.

Meilgaard, M. C., B. T. Carr and G. V. Civille, 2007. Sensory evaluation techniques. Fourth Edition. CRC Press. pp 275-279.

Ohlsson, T. and N. Bengtsson, 2002. Minimal processing technologies in the food industry. Woodhead Publishing Limited and CRC Press LLC, Boca Raton, Florida.

Oliveira, M. A., V. M. de Souza, A. M. Morato and E. C. Pereira, 2011. Microbiological quality of ready-to-eat minimally processed vegetables consumed in Brazil. Food Control 22: 1400-1403.

Ornelas-Paz, J. D. J., P. B. Zamudio-Flores, C. G. Torres-Cisneros, R. Holguín-Soto, O. P. Ramos-Aguilar, S. Ruiz-Cruz, J. C. Guevara-Arauza, G. A. González-Aguilar and V. Santana-Rodríguez, 2012. The barrier properties and potential use of recycledLDPE films as a packaging material to preserve the quality of Jalapeño peppers by modified atmospheres. Scientia Horticulturae 135: 210-218.

Parzanese, M., (ND). Vegetales mínimamente procesados. Retrieved: April 4, 2014. Available at: http://www.alimentosargentinos.gov.ar/contenido/revista/ediciones/55/ productos/R55_vegetales.pdf

Ramos, B., F. A. Miller, T. R. S. Brandao, P. Teixeira and C. L. M. Silva, 2013. Fresh fruits and vegetables-An overview on applied methodologies to improve its quality and safety. Innovative Food Science and Emerging Technologies 20: 1-15.

Rossaint, S., S. Klausma, U. Herbert and J. Kreyenschmidt, 2014. Effect of package perforation on the spoilage process of poultry stored under different modified atmospheres. Food Packaging and Shelf Life 1: 68-76.

Roura, I., M. Del Rosario and C. Valle, 2004. Shelf-life of fresh-like ready-to-use diced squash. Journal of Food Quality 27: 91-101.

Sandhya, 2010. Modified atmosphere packaging of fresh produce: Current status and future needs. LWT Food Science and Technology 43: 381-392.

Sasaki, F. F., 2005. Processamento mínimo de abóbora (Cucurbita moschata Duch.): Alterações fisiológicas, qualitativas e microbiológicas. M.S. Thesis, University of São Paulo, Brasil: pp 3-11.

Sasaki, F. F., J. S. Del Aguila, C. R. Gallo, M. M. Ortega, A. P. Jacomino and R. A. Kluge, 2006. Alterações fisiológicas, cualitativas e microbiológicas durante o armazenamento de abóbora minimamente procesada em diferentes tipos de corte. Horticultura Brasileira 24: 170-174.

Schlimme, D., 1995. Marketing lightly processed fruits and vegetables. HortScience 30 (1): 15-17.

Sgroppo, S. and C. Sosa, 2009. Zapallo anco (Cucurbita moschata, D.) fresco cortado tratado con luz UV-C. Facena 25: 7-19.

Silva, A., D. Oliveira, P. Yaguiu, M. Carnelossi, E. Muniz and N. Narain, 2009. Temperature and packaging of minimally processed pumpkin (Curcubita moschata). Ciência e Tecnologia Alimentos 29(2): 391-394. 
Soliva-Fortuny, R. C., P. Elez-Martínez and O. Martín-Belloso, 2004. Microbiological and biochemical stability of fresh-cut apples preserved by modified atmosphere packaging. Innovative Food Science and Emerging Technologies 5: 215-224.

Tripathi, J., S. Gupta and V. Kumar, 2011. Processing food for convenience: challenges and potentials. BARC Newsletter 322: 55-60.

USDA, 2014. Global Agricultural Trade System (GATS), Foreign Ag Service (FAS), Agricultural Research Service, United States Department of Agriculture. Available at: http://apps.fas.usda.gov/gats/BICOReport.aspx?type=pfood

Watada, A. E., K. Abe and N. Yamauchi, 1990. Physiological activities of partially processed fruits and vegetables. Food Technology 20(116-118): 120-122.

Wessel-Beaver, L., 2013. Release of tropical pumpkin 'Taína Dorada'. J. Agric. Univ. P.R. 97(1-2): 97-100.

Wessel-Beaver, L., O. Román-Hernández and L. E. Flores-López, 2006. Performance of new tropical pumpkin genotypes under varying cultural practices. J. Agric. Univ. P.R. 90(3-4): 193-206. 